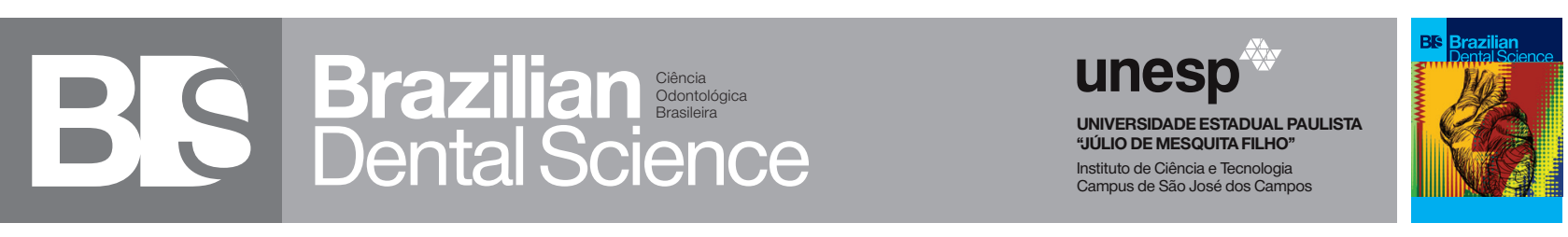

\title{
Antimicrobial and mechanical acrylic resin properties with silver particles obtained from Fusarium oxysporum
}

\author{
Propriedades antimicrobiana e mecânica de resina acrílica com partículas de prata obtidas a partir de Fusarium oxysporum \\ Tabata Prado SATO ${ }^{1}$, Celio Ilidio CONJO ${ }^{2}$, Rodnei Dennis ROSSONI ${ }^{3}$, Juliana Campos JUNQUEIRA ${ }^{3}$, Renata Marques de \\ MELO $^{1}$, Nelson DURAN ${ }^{4}$, Alexandre Luiz Souto BORGES ${ }^{1}$ \\ 1 - São Paulo State University (Unesp) - Institute of Science and Technology - São José dos Campos - Department of Dental Materials and \\ Prosthodontics - SP - Brazil. \\ 2 - Higher Institute of Health Sciences (ISCISA), Maputo, Mozambique. \\ 3 - São Paulo State University (Unesp) - Institute of Science and Technology - São José dos Campos - Department of Biosciences and Oral \\ Diagnosis - SP - Brazil. \\ 4 - Institute of Chemistry - University of Campinas - Campinas - SP - Brazil.
}

\section{ABSTRACT}

Objective: This study evaluated the effects of the incorporation of silver nanoparticles (AgNPs) obtained from Fusarium oxysporum on heat-activated acrylic resin (HAAR) and their influence on resin's surface roughness, hardness, color alteration and antimicrobial capacity against Candida albicans. Material and Methods: For this, 50 discs of HAAR $(2 \times 5 \mathrm{~mm})$ were produced and divided into three groups, Control: HAAR; Ag1: HAAR plus $0.539 \mathrm{mg}$ of AgNPs; and Ag2: HAAR plus $1.1 \mathrm{mg}$ of AgNPs. Knopp hardness (HK), surface roughness (Ra and $\mathrm{Rz}$ ) and color alteration according to the CIE Lab were measured. Specimens were then evaluated in vitro with regard to C. albicans biofilm formation through formed colony count (CFU/mL). Scanning Electron Microscopy (SEM) and Atomic force microscopy (AFM) analyses were performed. Results: The addition of AgNPs of both concentrations changed $\mathrm{Ra}, \mathrm{Rz}$ and HK significantly. There was statistically significant difference for $\mathrm{L}(\mathrm{p}=0.00) ; \mathrm{a} *(\mathrm{p}=0.00)$ and $\mathrm{b} *(\mathrm{p}=0.00)$ parameters. There were no differences between Ag1 and Ag2 biofilm formation, but the comparison of both with the control group presented a significant reduction $(p=0.0091)$ on biofilm formation. SEM and AFM images showed no signs of NPs clustering. Conclusion: It can be concluded tha AgNPs incorporation in HAAR was effective in reducing C. albicans activity, with a slight change in color and hardness of the material, being effective therefore, in regions such as the dental prostheses palate, which have lesser aesthetic appeal.

\section{KEYWORDS}

Acrylic resins; Silver; Antimicrobial agents.

\section{RESUMO}

Objetivo: Este estudo avaliou os efeitos da incorporação de nanopartículas de prata (AgNPs) obtidas a partir de Fusarium oxysporum em resina acrílica ativada termicamente (RAAT) e sua influência na rugosidade, dureza, cor e capacidade antimicrobiana contra Candida albicans. Material e Métodos: Para isso, 50 discos de RAAT $(2 \times 5 \mathrm{~mm})$ foram produzidos e divididos em três grupos, Controle: RAAT; Ag1: RAAT com 0,539 mg de AgNPs; e Ag2: RAAT com 1,1 mg de AgNPs. Foram medidas a dureza Knopp (DK), a rugosidade superficial (Ra e Rz) e a alteração da cor de acordo com o sistema CIE Lab. As amostras foram então avaliadas in vitro em relação à formação de biofilme de C. albicans através da contagem de unidades formadoras de colônia (UFC / mL). Foram realizadas análises de Microscopia Eletrônica de Varredura (MEV) e Microscopia de Força Atômica (AFM). Resultados: A adição de AgNPs de ambas as concentrações alterou significativamente Ra. $\mathrm{Rz}$ e DK. Houve diferença estatisticamente significativa para os parâmetros L $(p=0,00) ; a *(p=0,00)$ e b $*(p=0,00)$. Não houve diferenças entre a formação de biofilme Ag1 e Ag2, mas a comparação entre ambos com o grupo controle apresentou redução significativa ( $\mathrm{p}=0,0091$ ) na formação de biofilmes. As imagens de MEV e AFM não mostraram sinais de agrupamento de NPs. Conclusão: Pode-se concluir que a incorporação de AgNP no RAAT foi eficaz na redução da atividade de C. albicans, com uma discreta alteração na cor e dureza do material, sendo efetiva, portanto, em regiões linguais de próteses dentárias, que possuem menor apelo estético.

\section{PALAVRAS-CHAVE}

Resinas Acrílicas; Prata; Anti-infecciosos. 


\section{INTRODUCTION}

T nfections associated with pathological biofilms 1 are responsible for the vast majority of microbial infections in the body [1]. Therefore, it is important to develop antimicrobial materials with sufficient antimicrobial activity, no risk of microbial resistance, and easy to use in dynamic environments [2].

Silver is a very stable metal that is also, indeed, an effective antimicrobial material, only inferior to gold, and provides various therapeutic agentes [3]. Thus, the use of silver nanoparticles (AgNPs) for infection control is a growing scientific field, displaying potent antifungal effects, probably through destruction of microorganism membrane, deserving investigations for different applications [4].

The processes for obtaining AgNPs may be either physical, chemical or biological. Physical and chemical methods have some disadvantages due to the involvement of toxic substances and radiation.

Therefore, the biological methods concentrate most of the recent studies of the highly stable synthesis in critical aspects, such as types of organisms, genetical properties and enzyme activity [5]. In addition, this technique offers faster synthesis that leads to lower cost $[6,7]$.

The biological technique is based on the synthesis of silver ions from microorganisms such as bacteria and fungi [8]. Recently, efficient antibacterial activity was observed in AgNPs synthesized from the fungus Fusarium acuminatum against resistant and highly pathogenic bacteria such as Staphylococcus aureus, Salmonella typhi, Staphylococcus epidermidis and Escherichia coli [6].

In this context, Fusarium oxysporum is a fungus that adapts to different environments. It presents metal ions reduction enzymes such as nitrate reductase, hydrogenase, anthraquinone and naphthoquinone [9-11].

In the dental field, eco-friendly AgNPs proved itself useful against Candida albicans [12] and showed antibacterial activity against Streptococcus mutans [13]. The death of microorganism occured with the penetration of silver into the cells, inducing the releasing of substances such as sulfur and cell lysis $[7,14]$.

In this sense, it is known that $90 \%$ cases of denture stomatitis, disorder that causes mucosa inflammation and pain, mainly on the palate [15] and is caused by Candida albicans, which is an opportunistic pathogen and generally exists as a harmless commensal to humans [16]. Thus, controling such infections is of great interest in dentistry, especially in patients using full or partial dentures.

It is hoped that the AgNPs show antimicrobial action without affecting mechanical properties of the material. However, AgNPs added to a commercial composite resin affected the polymerization process and increased the leaching of resin componentes $[17,18]$. Moreover, the inclusion of silver in acrylic resins led to material bending resistance decrease [19].

This study aimed to analyze the microbiological response against C. albicans biofilm and the mechanical (roughness, microhardness and color) behavior of heat activated acrylic resin discs containing AgNPs obtained from Fusarium oxysporum. The null hypothesis was that the antimicrobial capacity and mechanical properties would not be different from the resin without AgNPs.

\section{MATERIALS AND METHODS}

50 discs were prepared using photopolymerizable resin (Filtek Z350, 3M ESPE) using metallic molds with holes of $5 \mathrm{~mm}$ diameter and $2 \mathrm{~mm}$ thickness. They were later included in silicone-filled muffle (VIPI SIL, Vipi). After silicone polymerization, the disks were removed. 
There were surface suitable for the inclusion of heat-activated acrylic resin (Clássico, Clássico Ltda, São Paulo, SP). 16 disks were made of acrylic resin with no silver incorporation (Control, Ct), 17 discs with $0.539 \mathrm{mg}$ of incorporated silver nanoparticles (Ag 1) and 17 discs with 1.1 $\mathrm{mg}$ of incorporated silver nanoparticles ( $\mathrm{Ag} \mathrm{2}$ ). After this inclusion the muffle was closed and submitted to slow polymerization process. A long cycle was performed at $74^{\circ}$ for $9 \mathrm{~h}$.

The divestment of the specimens was performed 24 hours later. All the disks were analyzed and sanded with sandpaper (\# 600) burrs and / or positive bubbles.

Silver nanoparticles were synthesized as previously described [8,20]. Thus, $10 \mathrm{~g}$ of Fusarium oxysporum biomass (strain 551) was added to $100 \mathrm{~mL}$ of distilled water and incubated $\left(28^{\circ} \mathrm{C} / 72 \mathrm{~h}\right)$. The culture was filtered, and the filtrate was mixed with $\mathrm{AgNO}_{3}(1.0 \mathrm{mM}$; SigmaAldrich, USA) (28oC/28 h) [8].

\section{Mechanical analysis}

\section{Roughness}

The surface roughness of the all specimens $(\mathrm{Ra}=$ Roughness average and $\mathrm{Rz}=$ Roughness depth) was analyzed through a roughness tester (Mitutoyo SJ 400, Kanagawa, Japan) then properly measured.

\section{Microhardness}

Microhardness testing was performed $24 \mathrm{~h}$ after roughness analysis using a digital microhardness tester (FM 700, Future Tech Corp., Equilam, Tokyo, Japan) with load of $50 \mathrm{~g}$ applied for $15 \mathrm{~s}$. One indentation was performed on each disk.

\section{Color Analysis}

At the International Commission on
Illumination CIE Lab: $\mathrm{L}^{*}, \mathrm{a}^{*}$ and $\mathrm{b}^{*}$, the color analysis was performed on a single face of each resin disks in a spectrophotometer Easyshade (VITA Zahnfabrik, Bad Säckingen, Alemanha). The samples were positioned on a white background. The spectrophotometer light was directed to one of its faces and the result of $L$ *, $\mathrm{a} *$ and $\mathrm{b} *$ was displayed on the device screen. The properties which determine material color (Lightness, Chroma and Hue) were then obtained. The lightness $\left(\mathrm{L}^{*}\right)$ is the optical property responsible for the lightness or darkness of the color in a vertical variation. Whereas the chroma ( $\mathrm{a}^{*}$ and $\mathrm{b}^{*}$ ) is the saturation of a color, varying radially, causing representation of the colors extremes of high and low intensity and the hue is the degree to which a stimulus can be described as red, green, blue, and yellow [21].

\section{Atomic force microscopy analysis (AFM)}

The analysis in atomic force microscopy was performed in a Veeco MultiMode $\mathrm{V}$ (Plainview, NY, EUA) with control station Nanoscope V.

\section{(FEG-SEM)}

Scanning Electron Microscopy analysis

The analyses in SEM were performed in a Field Emission Scanning Electron Microscope (FEG-SEM, JEOL 7500F).

\section{Microbiological analysis} groups

Microorganisms and experimental

The C. albicans was the microorganism used in this study (ATCC 18804). 24 specimens of HAAR were used, 8 for the control group (no silver nanoparticles addition) 8 for the Ag1 group (0.539 $\mathrm{mg}$ de $\mathrm{Ag}$ ) and 8 for the $\mathrm{Ag} 2$ group (1.1 mg de Ag). 


\section{Preparation of Candida Standardized Suspension}

From the fungal strain, one standardized suspension of microorganisms containing 106 cells $/ \mathrm{mL}$ was prepared. Initially, this strain was plated on Sabouraud dextrose agar (Difco, Detroit, EUA) and incubated at $37^{\circ} \mathrm{C}$ for $24 \mathrm{~h}$. After this period, the micro-organism was grown in Sabouraud broth and incubated at $37^{\circ} \mathrm{C}$ for 16 $\mathrm{h}$. The microorganism growth was centrifuged at $1300 \mathrm{Xg}$ for $10 \mathrm{~min}$, discarding the supernatant and the pellet was suspended in $10 \mathrm{~mL}$ of sterile saline solution $(\mathrm{NaCl}$ a $0,85 \%)$. The cell count was conducted by means of a spectrophotometer (AJX-1900, Micronal, Sao Paulo, Brazil) using a $530 \mathrm{~nm}$ wavelength.

\section{Biofilm formation}

For biofilm formation, the sterilized samples were placed into 24-well plates (Costar Corning, New York, USA) containing $2 \mathrm{~mL}$ of Brain Heart Infusion broth (Brain Heart Infusion-Difco, Detroit, USA) plus 5\% sucrose with the aid of a sterile forceps. Each well of the plate containing a specimen and BHI broth was inoculated with $100 \mu \mathrm{L}$ of of $C$. albicans. The plate was incubated under $75 \mathrm{rpm}$ shaking (Quimis) at $37^{\circ} \mathrm{C}$ for five days. The microorganism was inoculated once and BHI broth plus 5\% sucrose was changed every $24 \mathrm{~h}$. After the incubation period, the samples were transferred to next-row wells containing $2 \mathrm{~mL}$ of sterile saline solution, the plates were submitted to orbital shaking for 5 min (Solab, Piracicaba, Brazil). The washing process was performed twice in order to remove cells which did not adhere to specimens.

\section{Count $\mathrm{CFU} / \mathrm{mL}$}

After 48 hours of C. albicans biofilm formation, the specimens were placed in a Falcon tube containing $10 \mathrm{~mL}$ of sterile saline solution and homogenized for $30 \mathrm{sec}$ using ultrasonic homogenizer (Sonics Vibra Cell, São Paulo, Brazil) with $25 \%$ amplification with $50 \mathrm{~W}$ power for biofilm cells dispersion. Dilutions that followed were serially performed in saline solution and 0.1 $\mathrm{mL}$ dilution aliquots were plated with the aid of Drigalski handle, in duplicate, into Sabouraud Dextrose Agar plate (Difco, Detroit, USA). After an incubation period of $48 \mathrm{~h}$ at $37^{\circ} \mathrm{C}$, the colony forming units (CFU) per specimen were counted and log-transformed for data analysis.

\section{Statistical Analysis}

The results of CFU/specimen counts were statistically analyzed through ANOVA one-factor and Tukey test, with 5\% significance level, using GraphPad Prism program (La Jolla, CA, USA).

\section{RESULTS}

\section{Mechanical results}

The resin surface roughness analysis showed no statistically significant differences for both data RA ( $p=0.8)$ and RZ $(p=0.7)$. As for microhardness, both groups and the Ag1 Ag2 groups showed lower values than the control group $(\mathrm{p}=0.02)$.

With regard to color, $\mathrm{Ag} 1$ and $\mathrm{Ag} 2$ groups showed differences from control group. Analyzing $L^{*}$, darkening of the silver in groups in the composition and lower degree of yellow color in the direction of the axis and $b^{*}$ axis in the lower red coloration $\mathrm{a}^{*}$ were observed, where $\mathrm{p}=0.0$ for all.

During nanoscale analysis in AFM (Figure 1), it was observed that some protuberations were present in the groups containing nanoparticles, which were not seen in the control group.

Through SEM (Figure 2) image analysis, it was not possible to observe significant differences between the samples surfaces. It was only possible to detect silver particles above 25000x magnification. 
The statistical analysis is presented in the Table 1.

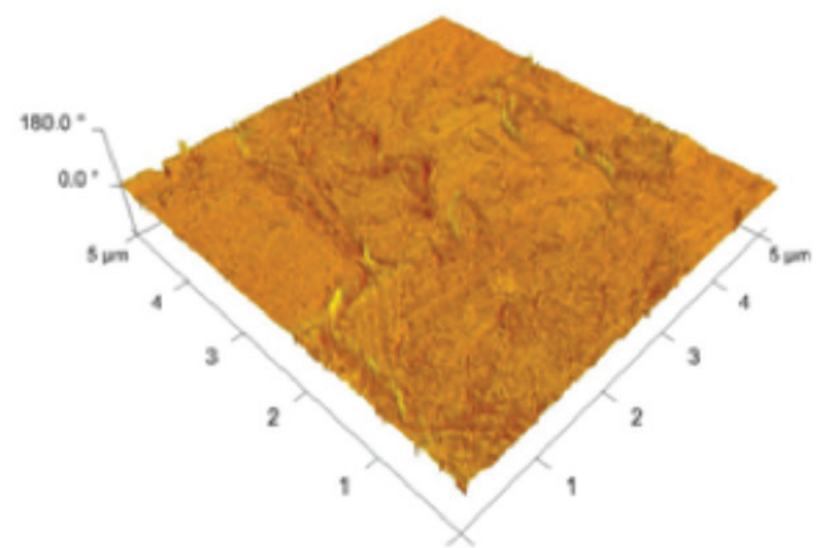

CONTROL
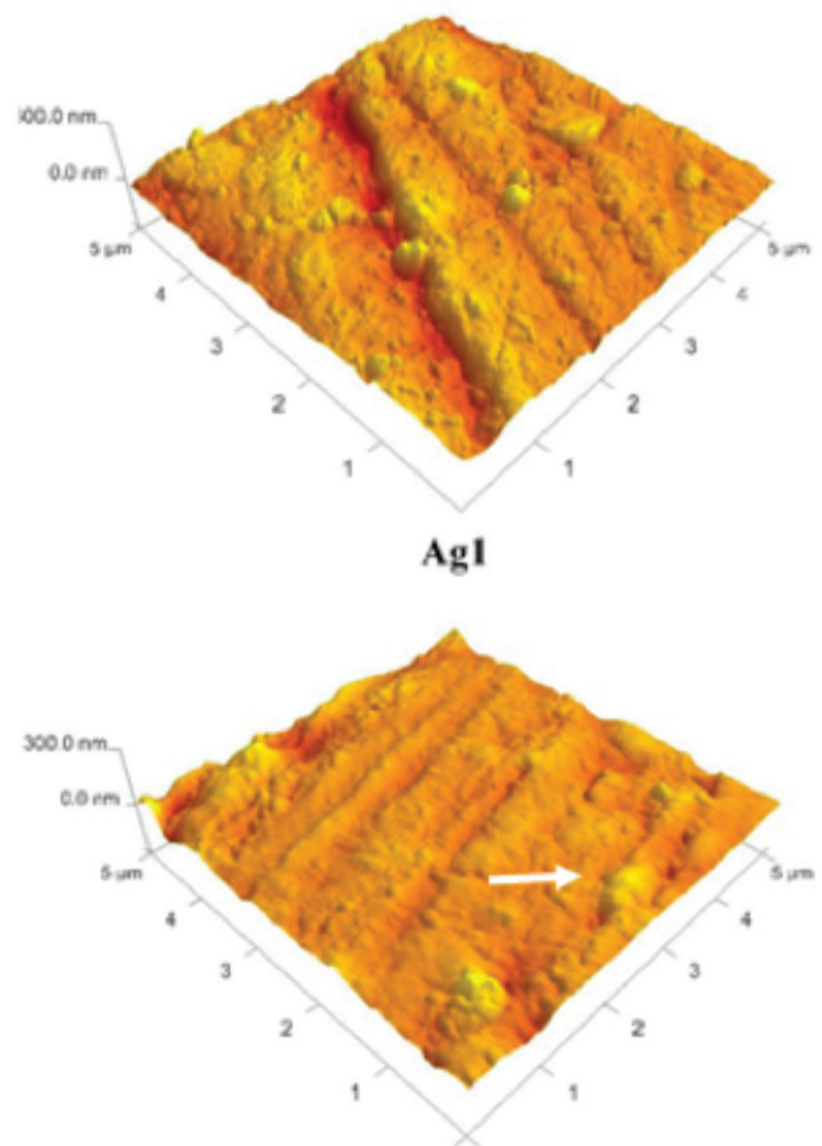

Ag2

Figure 1 - AFM of sample surface of control, Ag1 and Ag2 groups. The topographical features of control and experimental groups with different topography, but similar roughness. The arrows indicate potential nanoparticles on resin surface.

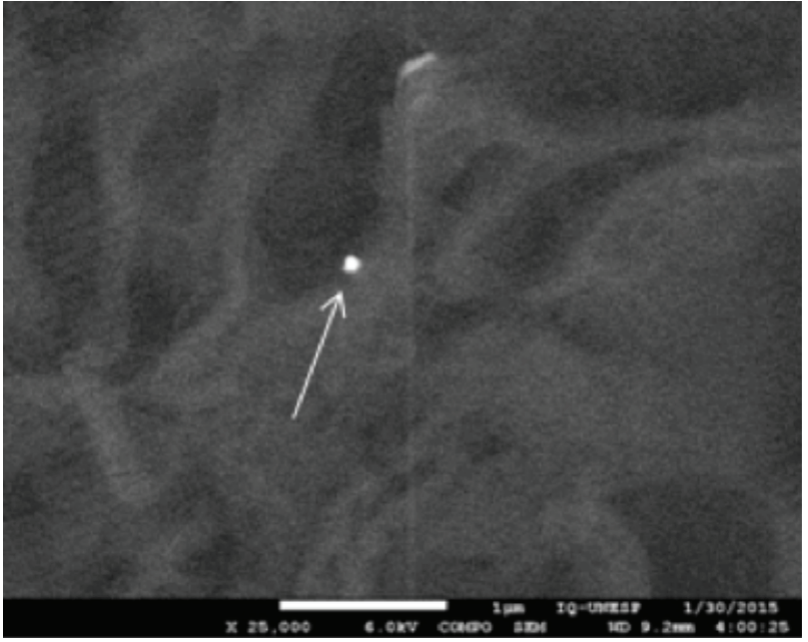

Figure 2 - Backscattered SEM image of Ag2 specimen, showing presence of silver particles (arrow).

Table 1 - Variance analysis (1-factor) for the properties of the control and experimental groups

\begin{tabular}{|c|c|c|c|c|c|c|}
\hline \multirow[t]{2}{*}{ Groups* } & \multicolumn{3}{|c|}{ Roughness } & \multicolumn{2}{|c|}{ Color } & \multirow{2}{*}{$\begin{array}{l}\text { Hardness } \\
\text { (KHN) }\end{array}$} \\
\hline & RA & RZ & L & $\mathrm{a}$ & b & \\
\hline Control & $\begin{array}{c}2.94 \\
( \pm 1.23)^{\mathrm{a}}\end{array}$ & $\begin{array}{c}17.06 \\
( \pm 7.91)^{\mathrm{a}}\end{array}$ & $\begin{array}{c}73.83 \\
( \pm 2.18)^{\mathrm{a}}\end{array}$ & $\begin{array}{c}29.38 \\
( \pm 2.84)^{\mathrm{a}}\end{array}$ & $\begin{array}{c}26.38 \\
( \pm 2.17)^{\mathrm{a}}\end{array}$ & $\begin{array}{c}17.06 \\
( \pm 7.91)^{\mathrm{a}}\end{array}$ \\
\hline $\mathrm{Ag} 1$ & $\begin{array}{c}2.89 \\
( \pm 0.73)^{a}\end{array}$ & $\begin{array}{c}17.61 \\
( \pm 4.16)^{\mathrm{a}}\end{array}$ & $\begin{array}{c}60.30 \\
( \pm 1.99)^{b}\end{array}$ & $\begin{array}{c}17.20 \\
( \pm 1.56)^{b}\end{array}$ & $\begin{array}{c}18.33 \\
( \pm 2.07)^{b}\end{array}$ & $\begin{array}{c}17.61 \\
( \pm 4.16)^{\mathrm{a}}\end{array}$ \\
\hline Ag2 & $\begin{array}{c}3.15 \\
( \pm 1.05)^{a}\end{array}$ & $\begin{array}{c}20.23 \\
( \pm 6.37)^{\mathrm{a}}\end{array}$ & $\begin{array}{c}60.58 \\
( \pm 2.59)^{b}\end{array}$ & $\begin{array}{c}15.47 \\
( \pm 0.78)^{b}\end{array}$ & $\begin{array}{c}15.05 \\
( \pm 2.27)^{c}\end{array}$ & $\begin{array}{c}20.23 \\
( \pm 6.37)^{b}\end{array}$ \\
\hline $\begin{array}{l}\text { ANOVA } \\
\text { results }\end{array}$ & $\begin{array}{l}p<0.0000 \\
f=0,2234\end{array}$ & $\begin{array}{l}p=0.7113 \\
f=0,3438\end{array}$ & $\begin{array}{l}p<0.0000 \\
f=139.21\end{array}$ & $\begin{array}{l}p<0.0000 \\
f=186.018\end{array}$ & $\begin{array}{l}p<0.0000 \\
f=132.87\end{array}$ & $\begin{array}{l}p<0.0192 \\
f=4.4168\end{array}$ \\
\hline
\end{tabular}

\section{Microbiological results}

The CFU/mL data of in vitro-formed biofilm of $C$. albicans in the control group and the groups treated with silver nanoparticles were analyzed. Figure 3 and 4 shows the increase in $\mathrm{CFU} / \mathrm{mL}$ of C. albicans when organized in biofilms for the control group and the groups added with silver nanoparticles resin. Regarding the formation of biofilm in the treated groups, we can see that there was significant reduction $(\mathrm{p}=0,01)$ compared to the control group showing the antimicrobial action of silver front fungal cells. There was no difference between the Ag1 and Ag2 groups, showing that the largest amount of silver in the Ag2 group did not influence antimicrobial action. 
The percentage reduction in CFU/ $\mathrm{mL}$ for Ag1, Ag2 and control groups were calculated and shown in Figure 4. AG1 group presented reduction of $74 \%$ of $C$. albicans biofilm and $\mathrm{Ag} 2$ group reduction percentage was $71 \%$.

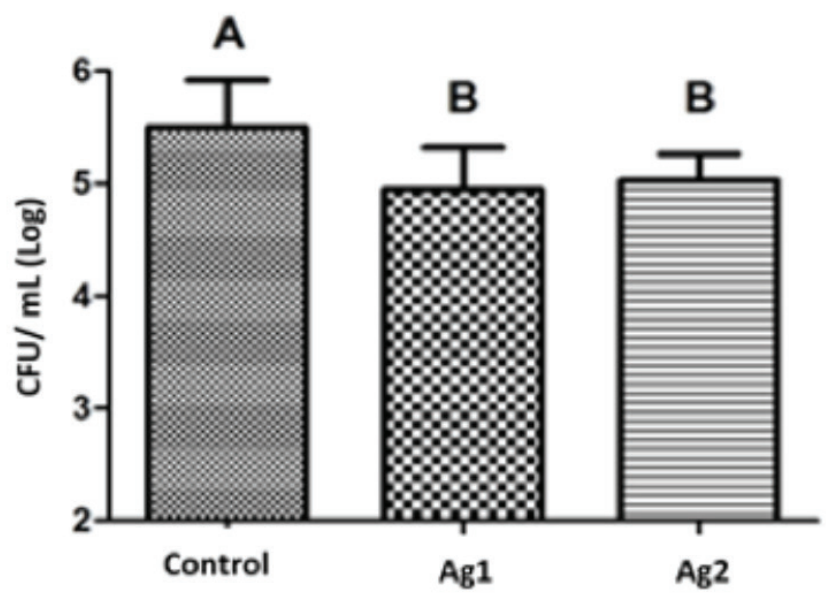

Figure 3 - Mean and standard deviation of CFU/ $\mathrm{mL}$ (Log) for C. albicans count when organized in monotypic biofilms.

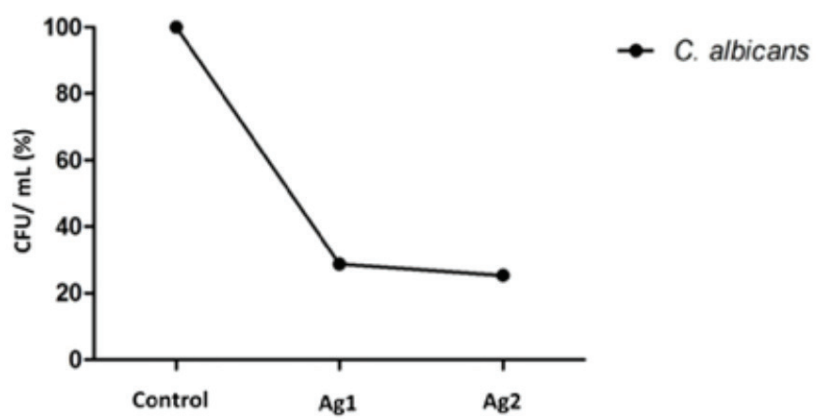

Figure 4 - Candida albicans reduction percentage of Ag2 and Ag1 groups compared to control group.

\section{DISCUSSION}

In this study, antimicrobial and mechanical properties of an acrylic resin with and without AgNPs was evaluated.

As for the mechanical properties, some studies presented that the addition of AgNPs had no effect in the resin strength [22], and for this study, no differences were observed in surface roughness; however, a change was found in resin coloration, which may cause displeasing aesthetics.

The color issue may not be a problem if the use of AgNPS is considered for acrylic portion in contact with the palate mucosa where infection with C. albicans is often manifested in denturewearing patients. Previous studies have shown C. albicans detected in $78 \%$ of these patients, with high pathogenic episodes of stomatitis and oral candidiasis [23].

The resin mechanical properties are probably related to its lower conversion degree $[24,25]$, which can proportionally decrease with nanoparticles amount increase. However, in this study, the lowest hardness values were observed in the group with the lowest amount of AgNPs.

As for the antimicrobial properties, significant reduction in C. albicans biofilm was found in groups with silver nanoparticles. However, there was no difference between the Ag1 and Ag2 groups, showing that the largest amount of silver did not impact antimicrobial action significantly.

These results are in agreement with previous study results that shown potent antifungal effects of AgNPs coating of denture base material - morphology deformation and inhibition of Candida adherence [26].

The material became darker when the amount of accumulated nanoparticles was higher. Therefore, the antimicrobial activity using even lower amounts of AgNPs than the used in Ag1 group must be evaluated in order to determine the proportion which least affects the original color of the material, aiming for aesthetic results.

The AFM and SEM images showed no nanoparticles agglomeration, Figure 1 suggests maybe clustering is occurring, but Figure 2 shows only one particle and no conclusion can be drawn. Indeed, particles detection at high magnifications also demonstrates that clustering has not occurred. It seems that agglomerations 
are observable only at higher concentrations of silver in the polymeric material, as noted in a previous study [27].

The specific mechanism of AgNPs in $C$. albicans is still controversial; however, the ultrastructural analysis showed no severe cell wall damage to AgNPs surrounding C. albicans cells or inside the cell cytoplasm with deposition of ions [28]. This could lead to a slow delivery of $\mathrm{Ag}$ ions increasing the time duration the NPs effects. Therefore, further studies are needed to understand the after-ageing behavior (mechanical and antimicrobial) of the acrylic resin containing AgNPs obtained from $\mathrm{F}$. oxysporum.

Therefore, this is one limitation of the present study and further inverstigation is needed to understand the after-ageing behavior (mechanical and antimicrobial) of the acrylic resin containing AgNPs obtained from $F$. oxysporum.

From this, the null hypothesis was rejected, because were found mechanical and microbiological differences in experimental groups in comparison to control group. Besides that, this sudy represent a further attempt to apply AgNPs in denture base materials because, taken together, these mechanical and microbiological data reveal possibilities to improve this material.

\section{CONCLUSION}

The groups with AgNPs incorporation, Ag1 and Ag2, were effective to reduce $C$. albicans activity, with a slight change in color and hardness in comparison to the control group, being clinical effective therefore, in regions such as the dental prostheses palate, which have lesser aesthetic appeal.

\section{ACKNOWLEDGMENTS}

The authors would like to thank Priscyla Daniely Marcato Gaspari for her time in synthesis of silver ions from microorganisms. The authors deny any conflicts of interest related to this study.

\section{REFERENCES}

1. Hall-Stoodley L, Costerton JW, Stoodley P.Bacterial biofilms: from the natural environment to infectious diseases. Nature Rev Microbiol. 2004;2(2):95-108. https://doi.org/10.1038/nrmicro821

2. Beyth N, Houri-Haddad Y, Domb A, Khan W, Hazan R. Alternative antimicrobial approach: Nano-antimicrobial materials. Evid Based Complement Alternat Med. 2015;2015:246012. doi: 10.1155/2015/246012. Epub 2015 Mar 16.

3. Russell AD, Hugo WB. Antimicrobial activity and action of silver. Progr Med Chem. 1994;31(iii-v):351-70. https://doi.org/10.1016/S0079-6468(08)70024-9

4. Kim KJ, Sung WS, Suh BK, Moon SK, Choi JS, Kim JG, et al. Antifungal activity and mode of action of silver nano-particles on Candida albicans. Biometals. 2009;22(2):235-42. https://doi.org/10.1007/s10534-008-9159-2

5. Iravani S, Korbekandi H, Mirmohammadi SV,ZolfaghariB. Synthesis of silver nanoparticles: chemical, physical and biological methods. Res Pharm Sci. 2014:9(6):385-406.

6. Durán N, Marcato PD, Durán M, Yadav A, Gade A, Rai M. Mechanistic aspects in the biogenic synthesis of extracellular metal nanoparticles by peptides, bacteria, fungi, and plants. Appl Microbiol Biotechnol. 2011;90(5):1609-24. https://doi.org/10.1007/s00253-011-3249-8

7. Durán N, Durán M, de Jesus MB, Fávaro WJ, Nakazato G, Seabra AB. Silver nanoparticles: A new view on mechanistic aspects on antimicrobial activity. Nanomedicine. 2016;12(3):789-99. https://doi.org/10.1016/j.nano.2015.11.016.

8. Durán N, Marcato PD, Alves OL, De Souza Gl, Esposito E. Mechanistic aspects of biosynthesis of silver nanoparticles by several Fusarium oxysporum strains. J Nanobiotechnol. 2005;3(1):8. https://doi.org/10.1186/1477-3155-3-8

9. Ottow JC, Von Klopotek A. Enzymatic reduction of iron oxide by fungi. Appl Microbiol. 1969;18(1):41-3.

10. Medentsev AG, Akimenko VK. Naphthoquinone metabolites of the fungi. Phytochemistry 1998;47(6):935-59. https://doi.org/101016/S00319422(98)80053-8

11. Baker RA, Tatum JH. Novel anthraquinones from stationary cultures of Fusarium oxysporum. J Ferment Bioeng. 1998;85(4):359-61. https://doi. org/101016/S0922-338X(98)80077-9

12. Panáček $A$, Kolář M, Večeřová R, Prucek R, Soukupová J, Kryštof V, etal. Antifungal activity of silver nanoparticles against Candida spp. Biomaterials. 2009;30(31):6333-40. https://doi.org/10.1016/j.biomaterials.2009.07.065

13. Espinosa-Cristobal L, Martinez-Castanon G, Martinez-Martinez R, Loyola-Rodriguez J, Patino-Marin N, Reyes-Macias J, et al. Antibacterial effect of silver nanoparticles against Streptococcus mutans. Mater Lett 2009;63(29):2603-6. https://doi.org/10.1016/j.matlet.2009.09.018

14. Feng QL, Wu J, Chen GQ, Cui FZ, Kim TN, Kim JO. A mechanistic study of the antibacterial effect of silver ions on Escherichia coli and Staphylococcus aureus. J Biomed Mater Res. 2000 Dec 15;52(4):662-8.

15. Pereira CA, Toledo BC, Santos CT, Pereira Costa ACB, Back-Brito GN, 
Kaminagakura E, et al. Opportunistic microorganisms in individuals with lesions of denture stomatitis. Diagn Microbiol Infect Dis. 2013;76(4):419-24. https://doi.org/10.1016/j.diagmicrobio.2013.05.001

16. Figueiral MH, Azul A, Pinto E, Fonseca PA, Branco FM, Scully C. Denturerelated stomatitis: identification of aetiological and predisposing factors - a large cohort. J Oral Rehabil. 2007;34(6):448-55. https://doi.org/10.1111/j.13652842.2007.01709.x

17. Durner J, Stojanovic M, Urcan E, Hickel R, ReichI FX. Influence of silver nanoparticles on monomer elution from light-cured composites. Dent Mater. 2011;27(7):631-6. https://doi.org/10.1016/j.dental.2011.03.003

18. Padovani GC, Feitosa PV, Sauro S, Tay FR, Durán G, Paula AJ, et al. Advances in Dental Materials through Nanotechnology: Facts, Perspectives and Toxicological Aspects. Trends Biotechnol. 2015 Nov;33(11):621-636. doi: 10.1016/j.tibtech.2015.09.005. Epub2015 0ct 21.

19. Sodagar A, Kassaee MZ, Akhavan A, Javadi N, Arab S, Kharazifard MJ. Effect of silver nano particles on flexural strength of acrylic resins. J Prosthod Res. 2012;56(2):120-4. https://doi.org/10.1016/j.jpor.2011.06.002

20. Durán N, Marcato PD, De Souza Gl, Alves OL, Esposito E. Antibacterial effect of silver nanoparticles produced by fungal process on textile fabrics and their effluent treatment. J Biomed Nanotechnol. 2007;3(2):203-8. https://doi. org/10.1166/jbn.2007.022

21. Anusavice KJ, Shen C, Rawls HR. Phillips Materiais Dentários. 12 ed. Elsevier Health Sciences: 2013
22. Köroğlu A, Şahìn 0, KürkçüoğluI, Dede DÖ, Özdemir T, Hazer B. Silver nanoparticle incorporation effect on mechanical and thermal properties of denture base acrylic resins. J Appl Oral Sci. 2016;24(6):590-6. https://doi. org/10.1590/1678-775720160185

23. Kawasaki K, Kamikawa Y, Hamada T, Hirabayashi D, Fujisaki J, Nagayama T, et al. A clinical study on the relationship between dentures and oral Candida species. Oral Therap Pharmacol. 2011;30(1):7-15. http://doi.org/10.11263/ jsotp.30.7

24. Salim N, Satterthwaite J, Rautemaa R, Silikas N. Impregnation with antimicrobials has an impact on degree of conversion and colour stability of acrylic liner. Dent Mater J. 2012;31(6):1008-13. https://doi.org/10.4012/ dm..2012-121

25. Ergun G, Nagas IC. Color stability of silicone or acrylic denture liners: an in vitro investigation. Eur J Dent. 2007;1(3):144-51.

26. Kamikawa Y, Hirabayashi D, Nagayama T, Fujisaki J, Hamada T, Sakamoto R, et al. In vitroantifungal activity against oral Candida species using a denture base coated with silver nanoparticles. J Nanomater. 2014(9177):1-6. http:// dx.doi.org/10.1155/2014/780410

27. Chladek G, Barszczewska-Rybarek I, Lukaszczyk J. Developing the procedure of modifying the denture soft liner by silver nanoparticles. Acta Bioeng Biomech. 2012;14(1):23-9.

28. Vazquez-Muñoz R, Avalos-Borja M, Castro-Longoria E. Ultrastructural analysis of Candida albicanswhen exposed to silver nanoparticles. PLoS ONE. 2014;9(10):e108876. https://doi.org/10.1371/journal.pone.0108876.

\section{Tabata Prado Sato}

(Corresponding address)

Av. José Longo, 777, São Dimas,

CEP 122452-00, São José dos Campos - S.P-Brazil.

Tel: +55 12 3947-9407

Date submitted: 2017 Dec 19

Email: tabata.sato@ict.unesp.br 